of the most valuable manuscripts and books which it is possible to accumulate for those who desire to explore the antiquities of Celtic literature and Celtic history." The Prime Minister went on to point out that it was a patriotic duty to assist the National Library and the National Museum by "adding to the treasures of which these great national institutions are to be the storehouse."

The National Library of Wales was founded by Royal Charter granted by H.M. the King in 1907, and entered upon the first stage of its existence on Jan. 1st of the present year in a temporary building at Aberystwyth, a building admirably adapted for the storing and cataloguing of the collections pending the removal to the permanent building which will be erected on a magnificent site of four acres close to the town of Aberystwyth, generously given for the purpose by the Right Hon. Baron Rendel. A large number of valuable gifts of books, manuscripts, prints, and drawings has already been made to form the nucleus of the library, which at this moment contains the finest collection of Welsh MSS. in existence, including the famous Hengwrt and Peniarth MSS. ; the collection of MSS. and early Welsh books made by Moses Williams, afterwards the property of the Earls of Macclesfield; and a number of MSS. derived from other collections. The Hengwrt Library includes not only the oldest texts of Romance literature, but also one of the most valuable MSS. of Chaucer's "Canterbury Tales" and other MSS. of great importance. The number of printed books already in the library is nearly 50,000. We need, however, very many books in Celtic literature and, even more, works of general reference, standard books in English and other languages, sets of transactions of literary, historical, and scientific societies, sets of the great periodicals, dictionaries, encyclopædias, and many other books of various kinds which we have no funds to acquire.

The Charter provides for the circulation of duplicate books for educational and research purposes, and this will be an important feature of the work of the library. The case of Wales is exceptional. Its University consists of three national colleges situated at Aberystwyth, Bangor, and Cardiff, while there are other important centres of educational activity, all urgently in need of the aid which it is hoped the National Library will be able to give to the higher branches of study. I wish particularly to state that while the Celtic side of the library must be its strongest feature, jet the object for which it was founded is much wider. It is to be a national library in the best sense, designed to afford in Wales that opportunity and encouragement for study and research hitherto wanting, and the lack of which has placed Wales at a disadvantage as compared with the other divisions of the United Kingdom and with other countries. England, Scotland, and Ireland enjoy great privileges under the Copyright Act which Wales has not received, and can hardly now expect to receive. Three libraries in England and one each in Scotland and Ireland are entitled to one free copy of every book published in the British Islands, while five or six other libraries which formerly had the same privilege now receive an annual grant from the public funds in lieu of it.

It is contemplated to proceed, as soon as circumstances will permit, with the erection of permanent buildings, and plans have been provisionally adopted. A sum of $£ 21,000$ has been subscribed towards the building fund. To erect a suitable and worthy building will cost a far larger sum. The contributors to the fund include residents in all parts of Wales and Monmouthshire, and many residing in London and elsewhere, including Welshmen abroad. The fund is a truly national one, and is made up of sums ranging from $£ 5000$ to $3 d$. The quarrymen of Festiniog and neighbourhood, for instance, made up a list of 744 names for a contribution of $£ 7018 s$., while the teachers of Cardiganshire agreed to make up $£ 100$. In Carmarthen, Swansea, Cardigan, Aberayron, and other centres, large and small, committees were formed to collect subscriptions. The contributors to the fund fully represent the Welsh people and their enthusiasm for the National Library is clearly shown. The library has also received gifts from kindred institutions. The British Museum, the Library of Congress at Washington, the Smithsonian Institution, the Corporation of London, the John Rylands Library, Manchester, the National Library of Ireland, and the principal public libraries have each sent sets of their publications, while the University of Oxford has made a grant of publications of the Clarendon Press. Several eminent scholars at home and abroad have also sent gifts of books, in many cases pontaneously, and with a graciousness which greatly enhances the value of their gifts.

The library is managed by a court of governors and a council, to which bodies members are nominated by H.M. Privy Council, by the county and borough councils of Wales and Monmouthshire, the University of Wales, and the three University Colleges. The maintenance is provided by a grant in aid from H.M. Treasury, which at present only provides for bare working expenses. No sum for purchasing the large number of necessary books is at present available.

I venture to ask those of your readers who feel an interest in this effort to bring within the reach of the residents in Wales the advantages which a National Library offers to make gifts of books or money for the book fund and donations to the building fund.

Communications may be addressed to me at the National Library, Aberystwyth.

I am, Sir, yours faithfully, John WILLIams, President.

Plâs, Llanstephan, Carmarthen, July 12th, 1909.

\section{METHODS OF BARBARISM IN ITALIAN HOSPITALS.}

To the Editor of THE LANCET.

SIR,- - The two events denounced in your columns under this title by a correspondent in Rome as having taken place in our hospitals-namely, the expulsion of a doctor from one of them on account of "moral turpitude" and of a sister from the other-are unfortunately true, but they took place with an interval of several years between them and have obviously been brought together in order to disparage our hospital institutions. I may add that the guilty persons received prompt and exemplary punishment. The other irregularities, of which, according to your correspondent, the two facts mentioned serve as a small demonstration, are not known to us, and we invite him to expound them in detail and to report concrete facts. Thirdly, the neglect of dying people on the part of sisters and nurses has never been shown to exist either in the Policlinico or in the other Roman hospitals. Fourthly, the confidence of the Roman public in the Policlinico and the other hospitals not only is not shaken but is steadily increasing, as is shown by the constantly rising number of patients and the fact that among these are many belonging to the leisured classes. Fifthly, our medical personnel is not inferior to that of other hospitals in other countries, and if the actual staff of assistants has not so far attained perfection, still, it has not all the fanlts attributed to it by your correspondent, while it is undeniable that it is improving steadily owing to carefully considered recruiting and a wider development of nursing schools. So much for the sake of truth. Then, as regards the close of your correspondent's letter, up to the present time we are really quite unaware of having any Anglo-American protectorate over our hospitals. The Roman hospitals live on their own incomes and on direct subsidies from the State, therefore if there is a limit to Anglo-American loyalty and liberality it is no concern of ours. In the hope that you will publish these few remarks of mine in your widely-read paper, I am, Sir, yours faithfully,

Professor Agostino CARDUCr,

Rome. President, \&c.

** We publish this letter with pleasure, but it seems to have escaped Professor Carduci's attention that our correspondent was quoting the Italian journals, and gives the reference to much of what he reports as appearing in the Tribuna.-ED. L.

\section{THE PROPOSED LEGISLATION IN REGARD TO ANESTHETICS.}

To the Editor of THE LANCET.

SIR,-The present situation with regard to this question requires the careful attention of the medical profession, and the remarks which follow have no relation whatever to the practice of anæsthetics as a specialty, but apply to the 
general practitioner of medicine in all parts of the kingdom. Dr. F. W. Hewitt has undertaken a most important work in bringing forward a measure to ensure protection to the public from the risks of general anæsthetics in the hands of persons who have not received a complete medical training. His proposals have been opposed by a portion of the dental profession partly on the ground that a very large number of medical practitioners are ignorant of the details and methods necessary for producing efficient anæsthesia for operations in the dental chair. In this statement they are perfectly correct, and this state of affairs has been due to the apathy and supineness of the medical student, who during his curriculum despises the idea of learning practical means of earning a livelihood from a secret conviction that he personally will be wafted into a consultant's chair where kneeling princes will pray for his advice. It is, however, absolutely essential that he should learn to give nitrous oxide and ether in the dental department of his hospital, so that he may become an efficient coadjutor of the neighbouring dental surgeon in that general practice which will have to support him and his family during his working life.

At the present moment, when the dental profession are making some claim to be more familiar with the use of nitrous oxide gas than the medical man, unless the latter opens his eyes to the fact that, by reason of his medical knowledge and training, he is the only proper person to induce and conduct general anæsthesia in all circumstances and derides at once to attend a dental hospital or department to obtain a proper facility with the apparatus and in the procedures involved, he will find during the next decade that a serious rivalry in this respect has been established and that he has cast away a valuable means of livelihood which is not only his birthright but a duty which he owes to the public who become his patients.

A medical practitioner is in a false position who, for no other reason than a want of activity in learning how to control the gas or vapour for the purpose in hand, stands by while his patient is subjected to the action of drugs which are potent enough to cause insensibility at the hands of others whose knowledge of medicine and therapeutics is less than his own.

Surely, if he thinks he is the proper person to be sent for to apply means of resuscitation in case of accident during anæsthesia he should be still more the fit person to prevent the accident from arising. It should be his task to choose the most suitable anæsthetic according to the opinion he forms of the patient's state of health, to produce complete anæsthesia, to discriminate during his administration of this anæsthetic between respiratory and circulatory symptoms, and to apply himself the remedial measures as required.

It is to be hoped that the teachers of anæsthetic administration in the hospitals of this kingdom will see to it that their pupils before qualification can properly administer nitrous oxide and ether for dental operations, and that the general practitioners will bestir themselves so that their present inefficiency in this respect may recede into the past. I am, Sir, yours faithfully,

$$
\text { H. BELlamy GaRDNER, }
$$

Formerly Instructor in Anæsthetics at Charing Cross Hospital, Harley-street, W., July 19th, 1909.

\section{A SYSTEM OF DIET AND DIETETICS.}

\section{To the Editor of THE LANCET.}

SIR,--Surely Dr. Young labours his points in endeavouring to support his statement that my views on the Salisbury diet are "incomplete and erroneous." As I pointed out in my previous letter, Salisbury sometimes prescribed 8 ounces a meal at the beginning of treatment; a statement made in my critic's first letter which contradicts his assertion that the "vital" error in my article has reference to quantity. Dr. Young, also, for the sake of his thesis, divided the food into three meals a day, although be complains that I did not refer to the number of meals, and regards that as a "fairly weighty error of omission." Now he assumes I have forgotten that Salisbury repeatedly emphasised that "five hours must elapse between meals." There is nothing in the original article which justifies either of these assumptions, and reference to it will show that the five hours' interval is mentioned in the statement that the water should be given at 6 and 11 A.M. and 4 and 9 P.M., and one or two hours before meals. Surely the reader can understand from those words that either three or four meals can be given and that even under a four meal régime the last one need not be later than 10 P.M. Talking of midnight, as. Dr. Young does, as the time when the fourth meal would be partaken of, is an exaggeration. The diet received adequate notice, and the idea in Dr. Young's mind that the quantity and number of the meals are the "prominent essentials" obscures the wood by the trees. The essential feature of the diet is that it is one of meat and hot water only. Further I may point out that the strain on the kidneys and organs concerned in the metabolism of protein was not ignored. Surely Dr. Young will not maintain that if only one or two ounces are given for a meal a five hours interval is essential. Many cases do quite well on four-hourly feeds. These are what I call the minutiæ of treatment, the modifications required by the individual patient. I have no reluctance in admitting that 11 ounces, or even 8 ounces, is an unduly large quantity for some cases at the beginning of treatment, but even Dr. Young cannot get away from the fact that Salisbury sometimes prescribed 8 ounces and that in the course of treatment patients sometimes take more.

I am, Sir, yours faithfully,

Edmund Cautuey.

Upper Brook-street, W., July 19th, 1909.

\section{MEDICAL TOPICS AND THE PUBLIC PRESS. \\ 7o the Editor of THE LANCET.}

SIR,-I am sorry to trespass again upon your space. The Editor of the Practitioner is of opinion that in my brief letter to you last week I have not cleared him from a suspicion of having sanctioned the republication of parts of my article in his July number. I am certainly pleased to do so, and to be assured that he had no responsibility in the matter. His permission was not sought.

July 19th, 1909. I am, Sir, yours faithfully,

\section{DISUSED INSTRUMENTS AND MEDICAL CURIOS. \\ To the Editor of THE LANCET.}

SIR,-The Medical Missions Committee of the Society for the Propagation of the Gospel are very grateful to an anonymous donor for a case of surgical instruments. They are always very thankful for such gifts for use in mission hospitals and dispensaries abroad or for the equipment of recently qualified doctors about to proceed to mission stations.

They would also, for exhibition purposes, be very grateful for gifts of native medicines, charms, or other articles used in the treatment of disease, the stock-in-trade of a Chinese doctor or chemist, or the dress, \&c., of an African witch. doctor. The object of showing these or similar articles at exhibitions is to contrast the apathetic indifference to human suffering, the heartless and stupid neglect of the sick, or the horrible cruelty to which they are subjected in lands where non-Christian beliefs hold sway, with the work of the medical (Christian) missionary, to whom all life is sacred, and who without distinction of class or creed ministers with loving skill to all alike. Gifts of such articles, accompanied by a brief description of their character and purpose, should be sent, with the name and address of the donor, to the Medical Missions Department, S.P.G. House, 15 Tuftonstreet, Westminster, London, S.W.

I am, Sir, yours faithfully,

F. H. MossE,

Chairman of the Medical Missions Committee, S.P.G.

\section{THE ROUTINE USE, BY THE OPEN METHOD, OF A MIXTURE OF CHLOROFORM AND ETHER.}

\section{7o the Editor of THE LANCET.}

SIR,-I have read with interest the paper by Dr. Hewitt and Dr. Blumfeld, and also the correspondence following. After the publication of Dr. Hewitt's lectures on General Surgical Anæsthesia in your columns in July, 1907, I tried the $\mathrm{C}_{2} \mathrm{E}_{3}$ mixture on the open mask and my results corresponded to those described. But I returned to what we call 